\title{
Developing a Model for Dropout Prevention and Intervention in Primary and Secondary Schools in Serbia: Assessing the Model's Effectiveness
}

\section{Jasminka Čekić Marković ${ }^{1}$}

Centre for Education Policy

\section{Jelena Radišić}

Department of Teacher Education and School Research, Faculty of Educational Sciences, University of Oslo

\section{Vitomir Jovanović}

Centre for Education Policy

\section{Tanja Ranković \\ UNICEF Serbia}

\begin{abstract}
The paper focuses on investigating the dropout phenomena and the need for its prevention and reduction within Serbian pre-university education. Understanding dropout as a multidimensional and system-level phenomenon, we offer a model for dropout prevention and intervention. The model considers the characteristics of schools in Serbia, together with the diversity of children under risk. Based on the findings from primary and secondary vocational schools ${ }^{2}$ where the model was piloted, we focus on the model's effectiveness as related to a reduction in the dropout rate, absenteeism, and grade repetition, together with the rise in students' overall achievement at the school level. The results suggest the model is largely effective in the reduction of dropout rate, absenteeism, and grade repetition, with some ambiguous findings in regard to the rise of students' achievement in primary schools.
\end{abstract}

Keywords: dropout prevention, Serbia, primary and secondary schools.

1 jmarkovic@cep.edu.rs

2 According to the International Standard Classification of Education (ISCED) 2011, primary schooling in Serbia is equal to the ISCED 1 and 2 level, while secondary vocational schools offer programmes at the ISCED 3 level. 


\section{Introduction}

The dropout phenomenon has been in the spotlight of many researchers and policy analysts. Although current findings link dropout with multiple risk factors and negative outcomes (Lansford, Dodge, Petit \& Bates, 2016), varying across different subgroups, the bulk of research and interventions still typically focuses on a single-component, individual, or small group interventions (Freeman \& Simonsen, 2015). Grounded in the notion of a multiplicity of possible risk factors for children to drop out of school and prevention and intervention measures proved to be effective, the paper proposes a model for dropout prevention and intervention. The model was developed within the project "Combating early school leaving in Serbia through effective dropout prevention and intervention measures at the school level", implemented by the UNICEF and the Centre for Education Policy, in cooperation with the Ministry of Education, Science and Technological Development of the Republic of Serbia. The analyses in this paper focus on the model's effectiveness through the prism of four indicators: reduction in the dropout rate, absenteeism, and grade repetition, together with the rise in students' overall achievement in ten pilot schools, where the model was implemented.

\section{Theoretical framework}

In order to understand why all children are not part of the education system and training, researchers and policy makers have adopted two concepts: early school leaving and dropout. The latter is in the focus of this paper.

Early school leavers (ESL) are defined as individuals aged 18 to 24 who are not enrolled in any education or training programme and have not obtained a secondary school level diploma within programmes that lasted more than two years (European Commission, 2013). These can be the students who have left school before ending their secondary school education or who have attended certain vocational schools and/or training programmes and their diploma is not equivalent to a secondary school diploma. Respectively, the students covered with ESL rate are also those who have interrupted a certain level of education before getting a diploma and have not enrolled in the next level of education (secondary school, in the countries where it is not obligatory) and thus were not covered by education ${ }^{3}$.

The concept of dropout covers all students who end their education before obtaining a diploma or do not complete the level of education they have

3 The definition always excludes those young people who participated in some form of education or training in the period of four weeks prior to the data time collection point across countries and surveys use this definition. The definition also excludes those students who left, or stopped their secondary education, but returned to finish it before the age of 25 . 
started, primary or secondary. The concept does not cover the children who did not enrol in school at allor the students who did not continue education after completing the levels of education that are considered obligatory by law.

Over the past decades, numerous studies have been investigating why some students drop out of the education system (Lansford, Dodge, Petit \& Bates, 2016; Prevatt \& Kelly, 2003; Rumberger, 1995; 2001; Rumberger \& Lim, 2008). In some, the question was raised having in mind the overall need to increase the size of qualified work force in the labour market (Wehlage \& Rutter, 1985), while others followed the idea of equity in education, especially in the studies from the mid 90-ties (e.g., Castelli, Ragazzi \& Crescentini, 2012). Regardless of the nature of the inquiry, researchers do agree that interrupting one's process of education and leaving the system is associated with a number of risk factors both at the student level and the school level, and with further negative life outcomes (Dynarski \& Gleason, 2002; Lansford et al., 2016; Pavlović Babić et al., 2013; Prevatt \& Kelly, 2003; Rumberger, 1995; Rumberger \& Rotermund, 2012; Witte, Cabus, Thyssen, Groot \& van den Brink, 2013).

Taken together, risk factors at the student level can be observed through the prism of individual students' attributes, such as academic failure, absenteeism or retention, and the so-called "status risk factors" (i.e., family characteristics, socioeconomic status (SES), receipt of social welfare benefits, etc.) (Duchesne \& Ratelle, 2010; Dustmann \& van Soeast, 2008; Rumberger, 1983; 1995; 2001; Rumberger \& Lim, 2008; Witte et al., 2013). At the same time, it is known that no single risk factor can accurately predict whether a child will drop out of education (Bowers, Sprott \& Taff, 2013; Lansford, Dodge, Petit \& Bates, 2016; Lee \& Burkam, 2003; Pavlović Babić et al., 2013). Instead, it has been widely agreed that a complex vision of each child is needed, especially having in mind that the impact of individual and status risk factors may change as the student grows older. For example, Godschmidt and Wang (1999) suggest that the importance of SES decreases with age.

Simultaneously, the studies in which the individual level factors have been controlled for indicate that school level factors (i.e., school policies, management, school size, relationships between teachers and students) explain significant variation in the students' dropout rates (Lee \& Burkam, 2003; Felner, Seitsinger, Brand, Burns \& Bolton, 2007). The schools lacking inclusion and acceptance culture facilitate students' dropout, especially when combined with other risk factors, such as poverty (Lee \& Burkam, 2003). In contrast, the schools able to ensure more quality relationships between students and their teachers contribute to the reduction in the number of students who interrupt their schooling (Felner at al., 2007; Riehl, 1999). A study focusing on schools in Serbia indicates that visible maltreatment, contempt and discrimination within teacher-student relationships, coupled 
with the individual level factors (e.g., low SES or behaviour maladjustment) may trigger students to dropout (Pavlović Babić et al., 2013). The authors emphasise that schools with higher dropout rates are also characterised by a lack of preventive measures related to dropout, a lack of substantial peer interactions, and almost total absence of parents' and students' involvement in the school life.

The very idea that dropout cannot be observed as a problem attributable to a single factor at either of the examined levels, and that wider contextual factors (e.g., the broader social situation, the municipality economic development, lack of transportation) need to be taken into account when looking at students at risk, has led to an increase in the conceptualisations of the dropout phenomenon as a system-level failure that requires a systemic intertwined intervention accounting for both individual and school level factors (Lee \& Burkam, 2003; Lehr, Hansen, Sinclair \& Christenson, 2003; Mac Iver, 2011). To date findings also suggest early interventions, even in lower primary grades, may lead to positive outcomes (Balfanz, Herzog \& Mac Iver, 2007), together with some recommendations on the practices fostering reduction in the dropout rate (e.g. Dynarski \& Gleason, 2002; Pavlović Babić et al., 2013). These include a systemic use of data for early identification of students at risk, tracking why students drop out, providing individualised support for students at risk tackling both academic and non-academic students' skills, and transforming the learning environments in order to provide individualised support at the highest level.

\section{The Context of the Serbian Education system}

In the context of education reforms across the world, the provision of quality education for all, together with the dropout and early school leaving prevention, have been the central topics of public policies ${ }^{4}$. In Serbia, dropout prevention is recognised as one of the priorities in attaining quality education for all (Government of the Republic of Serbia, 2012), setting the goal for early school leaving rates to be under $5 \% 5$, despite the factonly 8 years of primary

4 The Strategy of Development of the European Union, Europe 2020 (EU2020) states the reduction of the ESL among its pivotal themes, setting the limit of dropout rate to less than 10\% (European Commission, 2013). Inclusive education, together with dropout prevention, is one of the five strategic priorities set at the World Education Forum (UNESCO, 2015).

5 According to the Labour Force Survey of the Statistical Office of the Republic of Serbia (SORS), the percentage of students who leave school early (the rate of ESL) is $8.3 \%$ (Statistical Office of the Republic of Serbia, 2015). These data are not aligned with the data on dropout rate in primary education, the coverage by primary and secondary education and dropout rate in secondary education, provided by the Ministry of Education, Science and Technological Development. The data from the latest census in Serbia indicate that $12.03 \%$ of persons aged between 20 and 24 have not completed secondary 
schooling is considered obligatory by law. At the same time, a series of measures that were introduced by the Law on Foundations of the Education System (LFES) in 2009 (Official Gazette of RS, No. 72/2009) indirectly address the issue of dropout prevention in the system (e.g., the introduction of pedagogical assistants and Individual Education Plans (IEP), the extension of compulsory pre-school programme to nine months). In an attempt to put in force the envisioned principles of the educational system, the Amendments to the LFES in 2013 projected that special attention should be paid to the reduction of dropout rates, and the Law on Primary Education (Art. 26, Official Gazette of RS, No. 55/13), as well as the Law on Secondary Education (Art. 9, Official Gazette of RS, No. 55/13), stipulate that schools have the obligation to include measures for dropout prevention in their development plans, as well as to implement and monitor them ${ }^{6}$. The amendments also stipulate the obligation of the National Education Council (NEC) and the Council for Vocational and Adult Education (CVAE) to monitor, analyse and make recommendations to reduce students' dropout rate and to make proposals for further educational opportunitiesforthe individuals who have left the system (Art.14 and 16, Official Gazette of RS, No. 55/13).

However, the afore mentioned regulations and the existing mechanisms do not specify the exact measures, leaving to schools and relevant bodiesto design these measures themselves. In practice, this means that effective prevention and intervention measures are yet to be developed andtested and further attuned to the needs of the local communities and schools. Against this background, the paper introduces a model for dropout prevention and intervention and evaluates its effectiveness.

\section{The Dropout Prevention and Intervention Model}

In a nutshell, the Dropout Prevention Model (DPM) consists of three basic components (Figure 1), addressing the student and school level risk factors, as well as the wider social environment.

The first DPM component is focused on the accurate identification of at-risk students and the provision of individualised support through Individual Plans for Dropout Prevention (IPDP) of the identified students. Early warning and intervention system (EWIS) is based on the Instrument

education (including also those without completed primary education) (Statistical Office of the Republic of Serbia, 2013). The studies with the samples sensitive to members of marginalised groups (e.g. the Multiple Indicator Cluster Study by UNICEF) indicate that dropout is significantly higher among the students from these groups.

6 The Law on Primary Education (Art. 58, Official Gazette of RS, No. 55/13) stipulates that the primary school has the obligation to inform the parents/guardians that the child is not attending school. If the student does not attend school even after that, the school is obliged to inform the relevant bodies in the local self-government. 
for Identification of Students at Dropout Risk filled out byclass teachers who assess every student. The instrument included risk factors (such as SES, absenteeism, academic achievement) that potentially influence dropout for each student. A detailed explanation on the calculation of the dropout risk index (RI) is provided in Jovanović, Čekić Marković, Jokić and Ranković (2017).

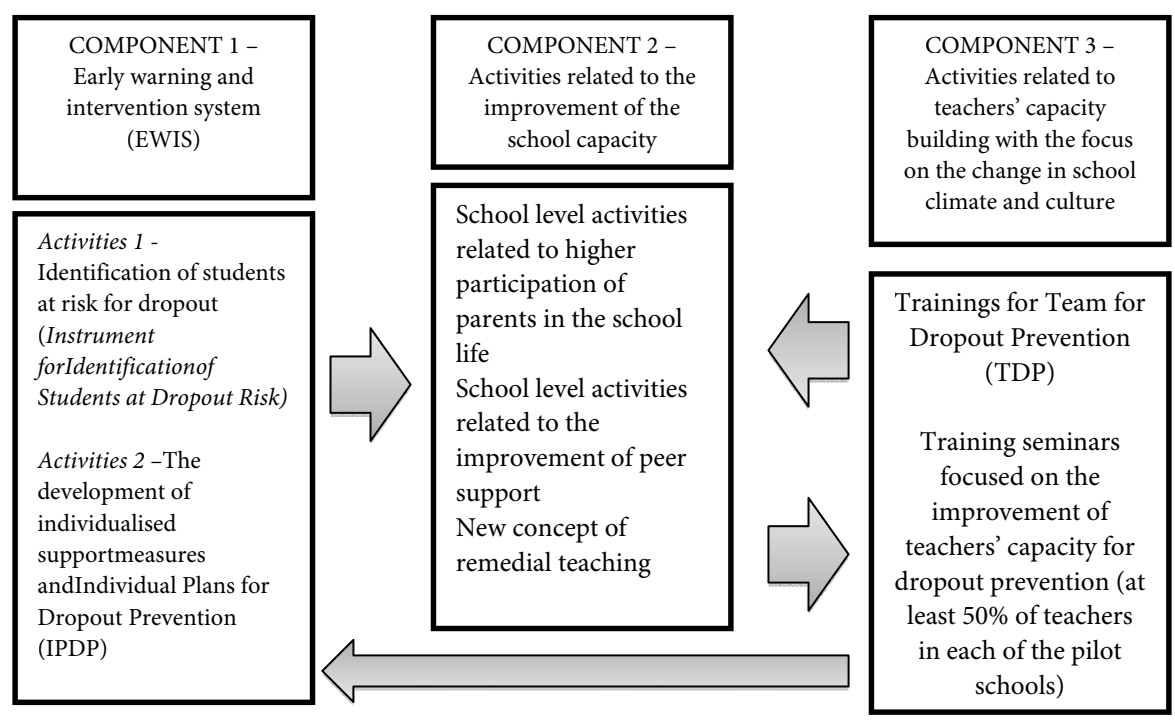

Figure1. Dropout Prevention Model (DPM) outline

For students identified as at-risk students, the Team for Dropout Prevention (TDP), in cooperation with the school professional associates and the coordinator for students at dropout risk, drafts an individual plan for dropout prevention (IPDP). The IPDP is developed with the aim of creating a focused action, which is planned, individualised, based on teachers' team work and monitored ${ }^{7}$. The development of the IPDP entails additional instruments aimed at assessing the student's motivation, teachers' expectations and the student's feeling of wellbeing ${ }^{8}$. Based on the analysis of grouping of the risk factors at the school level, each school received a specifically tailored instruction on how to approach the IPDPs development, depending on the student's characteristics and the combinations of the risk factors.

The second component of the DPM includes the activities implemented at the school level related to (1) parents' involvement in school life, (2) improvement of peer support and (3) modernised remedial teaching

7 The coordinator for student's IPDP is the teacher with whom the student has the closest relations.

8 School professional associates were trained for the use of these tests during the project. 
tailored as to fit relevant school needs, and supported by a newly developed guidebook (Kovač Cerović, Cenerić \& Jokić, 2017). Based on the needs analysis, different activities were incorporated in the three strands of the DPM's second component in each school (Table 1).

Table 1. Activities examples within Component 2 for each of the three component strands

\begin{tabular}{|l|l|}
\hline $\begin{array}{l}\text { Parents' involvement } \\
\text { in school life }\end{array}$ & $\begin{array}{l}\text { Parents volunteering, the involvement of parents of at-risk } \\
\text { students in the parents' council or with the school board, support } \\
\text { collaboration with teachers, parent-parent support for families } \\
\text { under risk, ensuring the participation of parents of at-risk students } \\
\text { in joint school activities etc. }\end{array}$ \\
\hline $\begin{array}{l}\text { Peer support } \\
\text { improvement }\end{array}$ & $\begin{array}{l}\text { Establishing peer mediation and mentoring teams, support } \\
\text { in learning and transition from class to subject teaching, peer } \\
\text { educative workshops, etc. }\end{array}$ \\
\hline $\begin{array}{l}\text { Modernisingremedial } \\
\text { teaching }\end{array}$ & $\begin{array}{l}\text { Remedial teaching modernised in methods and content, integrated } \\
\text { into school development, school evaluation, open, flexible, and } \\
\text { supported by research, teacher networking and a new guidebook for } \\
\text { schools and teachers. }\end{array}$ \\
\hline
\end{tabular}

The third DPM component covers capacity building, which includes different types of training seminars and mentoring in order to facilitate successful planning and implementation of the activities subsumed under Component 1 (e.g., supporting capacities for thecreation of the IPDP) and Component 2 (e.g., supporting capacities for working with parents, conceptualising remedial teaching). In this way, each DPM component was intertwined withother components, creating an integrated system of action, grounded in the idea that if a change within a system (e.g., school) is to be made, that same system needs to be equipped with the tools which disrupt the previous functioning of the system and facilitate the change (Engestrom, 1987; 2000; 2001).

\section{Focus of the Analysis}

Taking into account the multifactor and multilevel approach of the DPM in primary and secondary schools, our analyses focus on the DPM's effectiveness in connection to: (a) the reductionin the dropout rate, (b) the reduction in absenteeism, (c) the reduction of grade repetition, and (d) the improvement in students' academic achievement at the school level.

\section{Method}

Research design. The overall effectiveness of the DPM was measured following the design of the interrupted time series with multiple measurements before, during and after the DPM implementation (Lopez Bernal, Cummins 
\& Gasparrini, 2016). To identify the temporal dimension of the DPM application effects, data were collected for each school in three consecutive school years, starting from the beginning of the DPM application (beginning of the school year 2014/15, 2015/16 and 2016/17). The design included both quantitative and qualitative data analyses. The results section will focus on the data from the quantitative scope, primarily onthe questionnaire for assessing the situation in school (pre-test, post-test and intermediate phase) ${ }^{9}$.

Sample. The selection of schools to be included in the DPM pilot study was based on the composite scores of dropout risk calculated using the official data of the Republic of Serbia. As a result of in-depth analyses (see Appendix 1), 30 local self-governments were pre-selected, leading to the final selection of ten schools: four primary and six secondary vocational schools in seven municipalities.

Table 2. Characteristics of the ten schools based on the school questionnaire administered (pre-test)

\begin{tabular}{|c|c|c|c|c|c|c|c|c|c|c|c|}
\hline School & 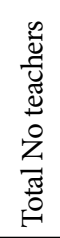 & 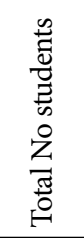 & 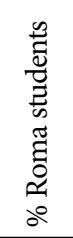 & 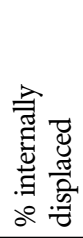 & 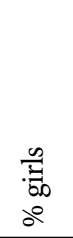 & 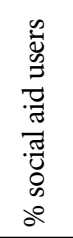 & 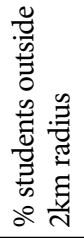 & 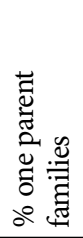 & 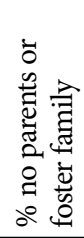 & 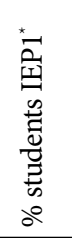 & 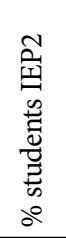 \\
\hline Seconc & 142 & 1468 & $22 \%$ & $31 \%$ & $29 \%$ & $28 \%$ & $51 \%$ & $21 \%$ & $0 \%$ & $0.3 \%$ & $0.1 \%$ \\
\hline Secondary school 2 & 85 & 875 & $3 \%$ & $1 \%$ & $63 \%$ & $29 \%$ & $72 \%$ & $19 \%$ & $1 \%$ & $0.1 \%$ & $0.1 \%$ \\
\hline Secondary school 3 & 77 & 793 & $4 \%$ & $3 \%$ & $61 \%$ & $20 \%$ & $82 \%$ & $18 \%$ & $2 \%$ & $0 \%$ & $0 \%$ \\
\hline Secondary school 4 & 90 & 746 & $4 \%$ & $1 \%$ & $41 \%$ & $38 \%$ & $20 \%$ & $19 \%$ & $3 \%$ & $1.3 \%$ & $0.4 \%$ \\
\hline Secondary school 5 & 71 & 743 & $1 \%$ & $17 \%$ & $54 \%$ & $4 \%$ & $72 \%$ & $12 \%$ & $1 \%$ & $1.2 \%$ & $0.3 \%$ \\
\hline Secondary school 6 & 51 & 325 & $13 \%$ & $0 \%$ & $36 \%$ & $64 \%$ & $62 \%$ & $7 \%$ & $0 \%$ & $1.5 \%$ & $0 \%$ \\
\hline Primary school 1 & 51 & 722 & $36 \%$ & $2 \%$ & $49 \%$ & $50 \%$ & $5 \%$ & $8 \%$ & $1 \%$ & $1.3 \%$ & $0.1 \%$ \\
\hline Primary school 2 & 51 & 665 & $16 \%$ & $0 \%$ & $49 \%$ & $47 \%$ & $15 \%$ & $6 \%$ & $0 \%$ & $0.3 \%$ & $0.9 \%$ \\
\hline Primary school 3 & 44 & 564 & $27 \%$ & $0 \%$ & $51 \%$ & $44 \%$ & $22 \%$ & $8 \%$ & $1 \%$ & $1.1 \%$ & $0.4 \%$ \\
\hline Primary school 4 & 35 & 237 & $10 \%$ & $0 \%$ & $42 \%$ & $21 \%$ & $2 \%$ & $21 \%$ & $1 \%$ & $4.2 \%$ & $9.3 \%$ \\
\hline
\end{tabular}

NOTE: IEP stands for Individualised Education Plans. IEP2 refers to Individualised Education Plans for students with more severe developmental challenges.

9 Apart from the quantitative measures collected in each of the participating schools, a number of guides for semi-structured interviews were created to capture different aspects of the school climate during the DPM intervention from the perspective of teachers, students and parents. In addition, supplementary data sources were used to increase the credibility of the DPM monitoring and evaluation framework (e.g. narrative reports of school mentors, data from external evaluation implemented by the Institute for Education Quality and Evaluation, prior and after the realization of the project). 
The criteria for the final selection of schools took into account the number of students who were at risk of dropping out (i.e., the number of Roma children living in extreme poverty, the number of refugee students and/or students who are internally displaced, the number of students from social assistance beneficiary families, the number of students in foster care, the number of student travellers ${ }^{10}$, the number of students who live in incomplete families), the school's human resources capacities to implement the project activities, the staff's motivation to participate in the project and their experience in cooperation with the local partners. The number of students at risk for dropping out and the school's staff motivation were the most important criteria when deciding on the final choice of schools for piloting the model.

Instrument. A questionnaire was developed to assess the situation in schools before and to track changes during and after the implementation of the DPM, allowing for specific school characteristics to be captured. This included information on the size of the teaching staff available, the ratio of students from the general population and vulnerable groups, grade point averages, the absenteeism rate, the dropout rate, grade repetition, etc. In addition, the questionnaire provided a description of the activities that the schools have already implemented towards preventing dropout (i.e., current school practices aimed at preventing dropout, collaboration with the local community, collaboration with parents, practices related to remedial classes, additional support for pupils and extracurricular activities organised by the school). The full scope of the data gathered by the questionnaire is provided in Appendix 2.

Variables. Data analysis wasbuilt around four indicators: the reduction in dropout per grade, the reduction in absenteeism at the school level, the reduction in average grade repetition and the improvement in students' average achievement (Table 3). All measures were observed at annual time points.

Table 3. Description of variables used in the analysis

\begin{tabular}{ll}
\hline School-level variables & Operationalisation \\
\hline Dropout rate & $\begin{array}{l}\text { The number of students who drop outper grade within the defined } \\
\text { school year. }\end{array}$ \\
Absenteeism rate & $\begin{array}{l}\text { The sum of excused and unexcused absences per student within a } \\
\text { school. For an absence to be treated as an excused child's absence } \\
\text { must be justified by the parent or health care service provider. }\end{array}$ \\
Grade repetition rate & $\begin{array}{l}\text { The number of students who repeat a grade per grade within the } \\
\text { defined school year. }\end{array}$ \\
Average achievement & $\begin{array}{l}\text { Students are graded on the scale from } 1 \text { to } 5 \text { (1 is a failing mark), } \\
\text { students achievement was observed as an aggregation at grade and } \\
\text { school level at the end of the school year. }\end{array}$ \\
\hline
\end{tabular}

10 Students living outside the school residence (nearby village or town, intercity transport is required to reach the school). 
Analysis. The analysis was performedusing SPSS. In this paper, we use both grade and school level data focusing on all students in the pilot schools.

\section{Results}

The results section comprises of four major blocks, each block outlying the results related to the four indicators we focus on: the reduction in the dropout rate, the reduction in the absenteeism rate, the reduction in grade repetition and the improvement in students' achievement.

\section{Reduction in the Dropout Rate}

The data related to the dropout rate indicate variability in its levels in pilot schools prior to the DPM implementation (during the school years 2011/12. 2012/13. and 2013/14. see Graph 1). On the average, schooling was interrupted for 221 students per school year in 10 pilot schools, prior to the project. However, even in the first year of the DPM implementation, there was an indication of a steep decline, which continued until the project completion.

At the end of the project, after two years of DPM implementation, only 75 students in total left their schools. As shown in Table 4, the model was the most effective in the situations when the dropout rate was the highest - in the first grade in secondary vocational schools when students had to substantially adjust to the new environment.

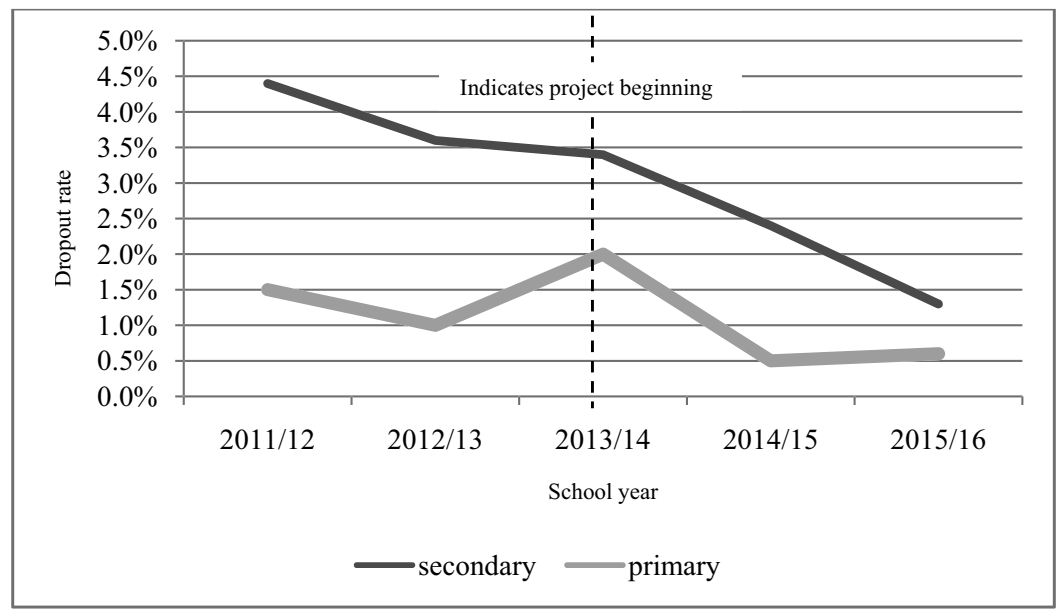

Graph 1. Dropout Rate in Pilot Schools

Upon identifying the grades with highest dropout rates in the pre-test, secondary vocational schools were instructed to provide special attention and 
support to students entering those schools. It is likely that this had led to the highest reduction of dropout rates in both grades because the individual support started in the first grade and continued in the consecutive grade. A similar trend was also noticeable in primary schools for grades five and six. Accordingly, those schools were also instructed to focus their individual support on the students attending the fifth and sixth grade.

Table 4. Data on pre-test and post-test related to the number of students who dropped out of school (average per grade for 3 years)

\begin{tabular}{|c|c|c|c|c|c|c|c|c|}
\hline & \multicolumn{8}{|c|}{ Primary Schools } \\
\hline & Grade & Grade & Grade & Grade & Grade & Grade & Grade & Grade \\
\hline & 1 & 2 & 3 & 4 & 5 & 6 & 7 & 8 \\
\hline Prior to implementation & 1.7 & 5.3 & 3.3 & 4 & 6.3 & 7 & 5.7 & 1.3 \\
\hline \multirow{3}{*}{ After implementation } & 0 & 1 & 0 & 3 & 2 & 3 & 2 & 1 \\
\hline & \multicolumn{8}{|c|}{ Secondary School } \\
\hline & Grade & Grade & Grade & Grade & & & & \\
\hline \multirow[t]{2}{*}{ Prior to implementation } & 1 & 2 & 3 & 4 & & & & \\
\hline & 123.3 & 40 & 19 & 5.6 & & & & \\
\hline After implementation & 26 & 17 & 18 & 1 & & & & \\
\hline
\end{tabular}

NOTE: The cells represent the number of students who dropped out. The number of students who dropped out prior to implementation refers to the average number of studentsper year who dropped out of school within three years before the project implementation.

If we solely focus on the students who were assessed to be at risk and received the IPDP (139 in primary and 311 in secondary schools), only fivestudents (3.5\%) dropped out of primary education and twenty (6.4\%) out of secondary education. Bearing in mind that those were the students identified to be at very high risk of dropping out, our findings suggest a high efficacy of the IPDPs.

\section{The Improvement in Students' Academic Achievement}

Our data indicate that the DPM implementation did not contribute to an improvement in students' achievement in vocational schools. It appears that the GPAs at the end of the school year 2015/16 were even slightly lower than the ones prior to project implementation (the average GPA across all four grades was 3.34 before the DPM and 3.22, after the project completion). This can be potentially explained as at least in part related to the decrease in grade repetition, leading to a larger number of students who had the minimal passing grade (i.e., 2) to remain in the sample. In addition, the reduction in the dropout rate could also have lowered the average GPAs of the schools, since students who experience various challenges and generally tend to have lower grades, were now more likely to stay in school as a result of the DPM intervention. 
The situation in primary schools appears to be quite different. Positive changes in students' achievement in primary schools are more prominent (Graph 2), especially during the period of transition to subject teaching, where the dropout rates used to bethe highest. The average grades in the $5^{\text {th }}$ grade increased from 4.0 to 4.2 , and in the $6^{\text {th }}$ grade from 3.8 to 4.2 . Such a result may indicate a greater willingness of teachers in primary schools to meet students' needs and to individualise their instruction, thus providing students with additional support when needed. All these activities were in the focus of the second DPM component, linked to the better implementation of remedial teaching.

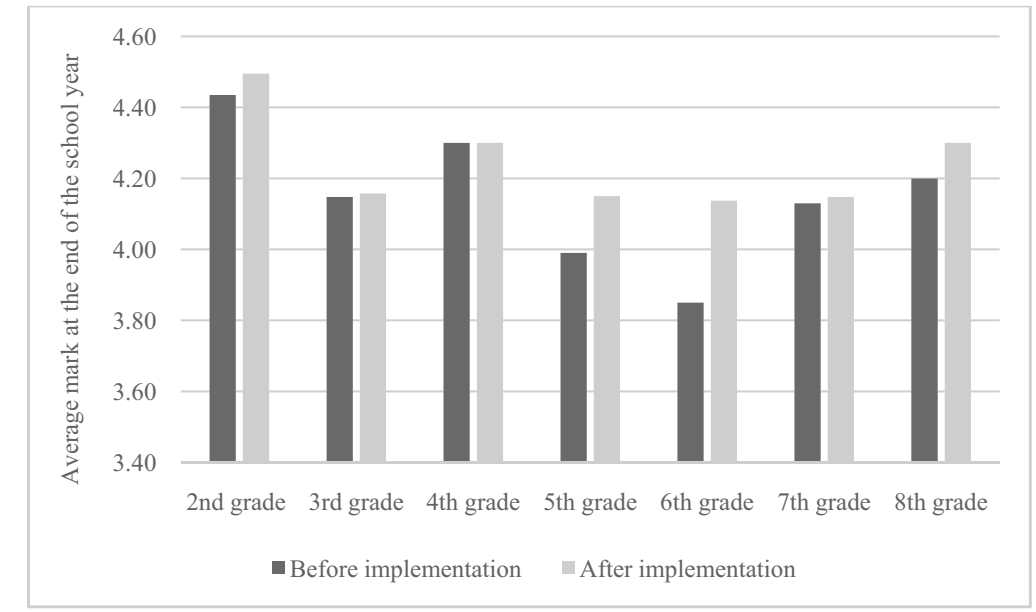

Graph 2. Students' achievement prior to and after the implementation of the DPM in primary schools

\section{The Absenteeism Reduction}

Absenteeism was observed through the prism of both excused and unexcused absences per student. Taking into account possible differences in schools related to observing absenteeism, practices and trends were analysed between and within schools. In secondary schools, the number of unexcused absences does not differ much between grades and ranges from 10 to 17 per student in one school year, while there are 120 excused absences on the average. The situation in primary schools is somewhat different. All but one school ${ }^{11}$ had very low numbers of unexcused absences per student, while the average number of excused absences amounted to 67 per school.

11 The explanation about the situation in this particular school is provided in the section related to absenteeism in primary schools. 
The data for secondary schools suggest a large decrease in absenteeism per student prior and after the implementation of the model, while the absenteeism trends per grades remain similar (i.e., it is still the lowest in the first grade of the secondary school) (Graph 3). The schools attribute this result to the activities within the model's Component 2, which sought to increase students' presence in class (peer support, information on absence, the inclusion of parents, support measures for students, etc.). On the whole, prior to the implementation of the DPM, the average absenteeism amounted to 117 classes per student, but after the implementation of the project, it was reduced to 83 classes per student for the school year.

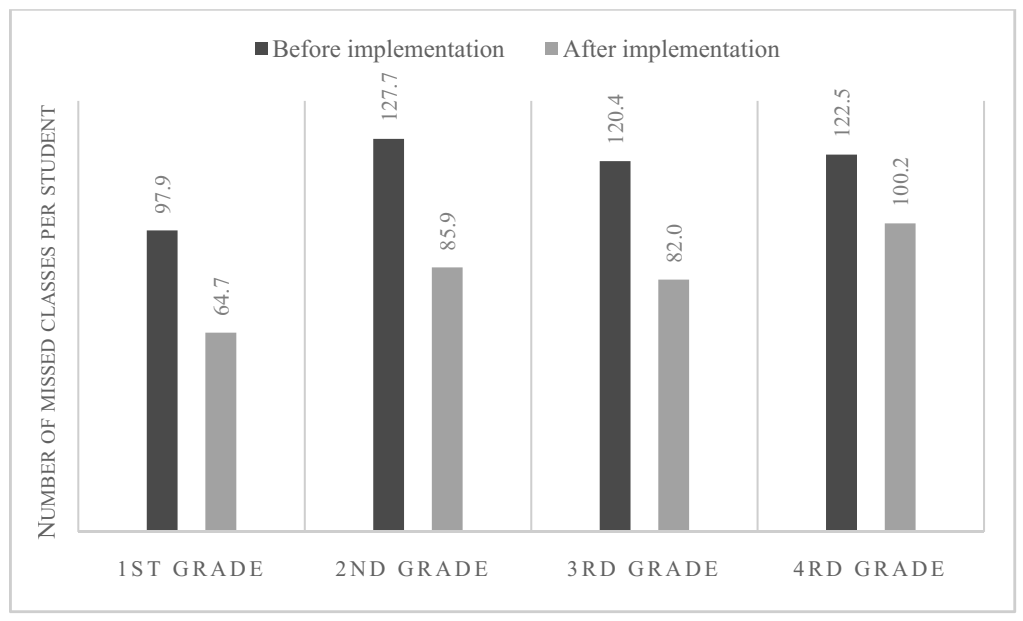

Graph 3. Total absences (excused and unexcused) per student in the school year prior to and after the implementation of the DPM in secondary vocational schools (2013/14 and 2015/16)

As for the data related to primary schools, the analysis showed a huge increase in the absenteeism rate only in one rural primary school, namely in the number of unexcused classes for the students who left the country with their families for seasonal work. This school was observed as a sole entity, against other primary schools involved in the project, and the data related to this school were not included in further analyses on absenteeism before and after the project completion.

The pattern for the rest of the primary schools has shown a reduction in absenteeism before and after project completion (from 77 absences per studentto 68 absences per student, excused and unexcused absences taken together). The highest reduction has been observed for the second and sixth grade (see Graph 4). In one school, with the fewest cases of the families migrating outside of the country for work, the reduction was even more evident, from 89 to 57 absent classes per student. 


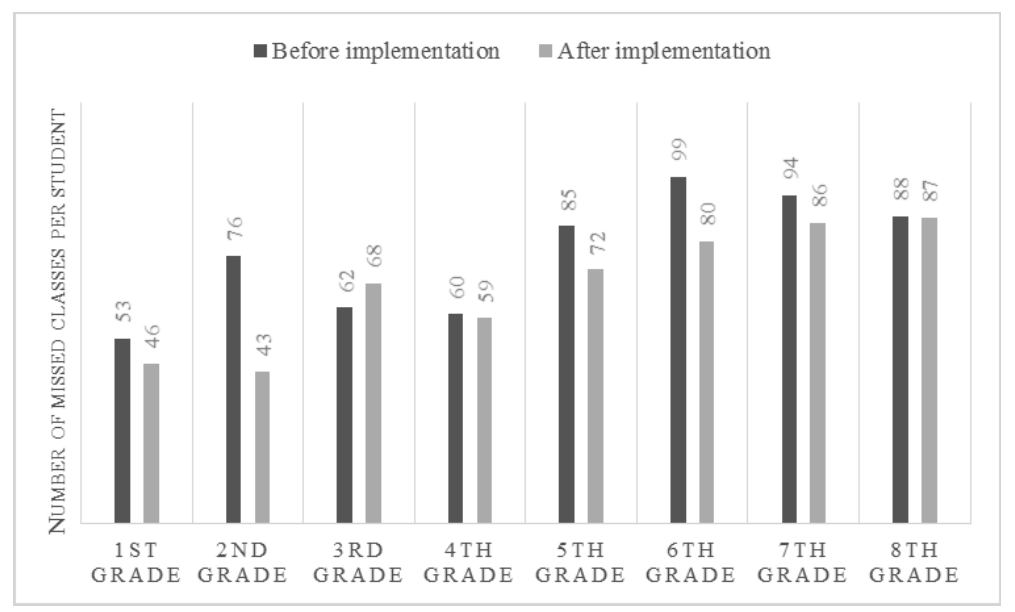

Graph 4. Total absences (excused and unexcused) per student in the school year prior to and after the implementation of the DPM in primary schools (2013/14 and 2015/16)

\section{The Reduction in the Grade Repetition Rate}

The grade repetition rate in all ten schools before the start of the DPM implementation was $2.1 \%$ on the average. By the end of the project, the overall repetition rate was reduced to $1.7 \%$. This means that before the start of the project, a grade was repeated by 162 students in total, while at the end of the project the grade was repeated in all ten schools by 125 students. In six out of ten schools the reduced repetition rate shows a linear trend. In four schools the number of children who repeated agrade has increased. However, a deeper examination of the results in these four schools indicates some distinctive patterns which can explain the 'repetition increase'.

In two primary schools (out of the four, see Graph 5) the repetition rate may be more attributable to the usual variability between generations. In one vocational school, there was a complete absence of repetition before the start of the project, while in the last year of the DPM implementation one student repeated a grade. In the other vocational school, the repetition rate was increased by one student. 


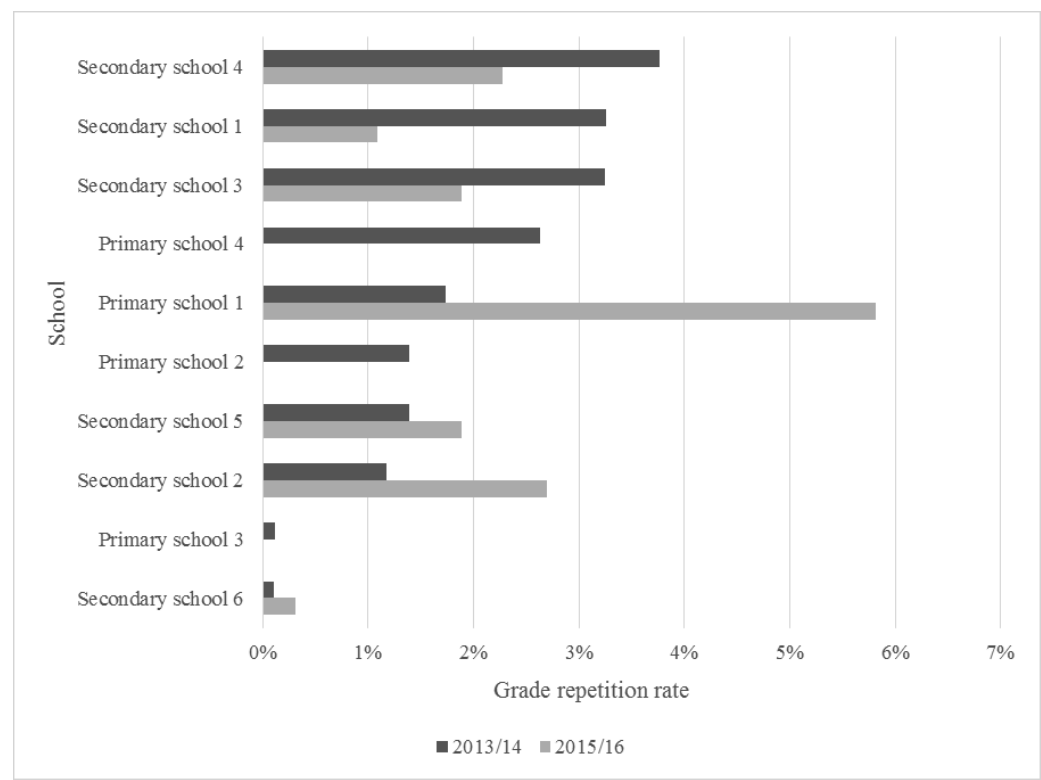

Graph 5. Grade repetition rate prior to and after the DPM implementation

In two schools (one primary and one secondary, see Graph 5) where the rate was visibly increased, we may point to specific school-level factors that are most likely associated with such an outcome. One secondary vocational school reported a considerably higher repetition rate, explaining it by an unusually inflexible attitude of a number of teachers and their unwillingness to provide additional support to students, coupled with noticeable resistance in some of the teaching staff to the ongoing changes. Similar issues were also reported with regard to one primary school, which proved to be less successful in implementing the DPM. This finding, however, stresses the need to additionally address the practices related to capacity building within Component 3 and search for the ways in which these can be further attuned as to more efficiently build on teacher competences in providing more individualised instruction.

\section{Discussion}

The paper purported to examine the effectiveness of a model designed to prevent student dropoutby addressing school dropout as a systemic phenomenon, affected by risk factors at both the student and school level. The model was implemented in four primary and six secondary vocational schools from different parts of Serbia, perceived to be the most vulnerable with regard to student dropout. Although the effectiveness of the model was 
examined with both quantitative and qualitative methods of inquiry, this paper addressed four quantitative indicators: the dropout rate, absenteeism, grade repetition rate, and school achievement. The results were interpreted in the light of the system for early identification of students at risk of dropout, coupled with the intervention in the form of individual plans dedicated to the reduction of dropout in identified students (Component 1), with reference to specific activities within Components 2 (the modernised concept of remedial teaching, parents' and peers' support) and 3 (strengthening school capacities in the activities covered by the previous two components).

Our findings suggest a substantial reduction in student dropout- around $66 \%$ across ten pilot schools. Having in mind the particularity of the schools, i.e., that they were chosen for being themost vulnerable schools in Serbia, we believe that the model could be similarly effective in the schools that deal with fewer challenges, but still, encounter students who are at the risk of dropout. The model was equally effective in primary and secondary schools, a finding important from both the empirical and the practical aspect. Previous research has shown that risk factors for students' dropout may change as the students grow older (Goldschmidt \& Wang, 1999). Yet,the proposedmodel seems to be able to successfully address these challenges across different ages. At the same time, our finding of the higher reduction in the dropout rate in primary schools reconfirms the claims that intervention as early asin primary school grades may lead to positive outcomes related to dropout (Balfanz et al., 2007).

Again, from the perspective of policy makers, the finding related to a steep decline in the dropout rate is especially important when observing secondary schools, which are still not part of compulsory education in Serbia. The fact that the model has managed to reduce students' dropout in them and, more importantly, in those grades where the dropout was the highest (grade one in secondary education) is more than encouraging. Having in mind the Strategy of Education in Serbia by 2020 (Government of the Republic of Serbia, 2012) to reduce the overall school leaving to 5\%, the DPM could potentially be an effective tool that schools can use to reach that goal.

Among the recommendations previously given in the literature on effective prevention models, is the one related to the need for schools to identify, track and support the students at the risk of dropout (Dynarski \& Gleason, 2002; Pavlović Babić et al., 2013). The fact that out of all students who received support (450 students across ten participating schools), only 5.5\% dropped out, speaks in favour of the importance of tracking and identifying students at risk as early as possible. At the same time, the fact that such students often face multiple life obstacles (e.g., poverty, incomplete families, behaviour problems, lower acceptance in school), which make it difficult for them to stay in school, reconfirms the need for an approach that addresses dropout as a system-level failure (Lee \& Burkam, 2003; Lehr et al., 2003; Mac Iver, 2011). 
Furthermore, particular findings in our study suggest that reaching out to students may be even more effective if the identification of students is done on a regular basis. Within the project implementation timeline, an early identification system of students at risk was used prior to the IPDP. A number of other measures were also introduced in each school to increase students' presence, as part of the activities within Component 2. As such, they have contributed to the overall reduction in the dropout rate. Still, the reduction was the highest among the students under the IPDP. This implies that if the instrument is used at another time point new students could be potentially identified as in need and an IPDP can be made, keeping them in school. Furthermore, the results on dropout rates per grade have suggested dropout to be possible inevery grade, meaning that different students may be at risk at different time points. Thus, a regular identification may facilitate the identification of different students and contribute to addressing the dropout problem even more effectively at the school level.

Among other individual students' attributes included in the analysis absenteeism, achievement and grade repetition (Rumberger, 1983; 1995; 2001; Rumberger \& Lim, 2008; Witte et al., 2013), the results seem to be mixed. In secondary schools, average achievement has not improved after the project implementation. We suggested previously that these findings need to be further explained and examined taking into consideration the achievement of students who were perceived as at risk, but had managed to stay in school. Importantly, the improvement in academic achievement has been observed in the so-called transition grade in primary schools, from class to subject teaching. This may imply that those teachers were more attuned to the needs of the students (see Component 2 of the model) through the use of remedial practices and therefore were readier to tailor their teaching practices to students' specific needs. This is in line with previous findings that the schools fostering inclusion and more quality relationships between students and their teachers are more likely to yield positive outcomes related to dropout risk factors (Lee \& Burkam, 2003; Felner et al., 2007).

In connection to that, a decrease in grade repetition was observed in six out ten schools. In two schools with an increase in this domain, the inflexible attitude of some teachers and their unwillingness to provide additional support to students through revised remedial teaching was described in school reports as contributing to such outcomes, a finding similar to the one reported by Lee and Burkam (2003) and Felner and colleagues (2007). From the perspective of the model, the finding stresses the need to further attune the capacity building module related to differentiated instruction within Component 3.

Finally, our findings about absenteeism suggest almost the same patterns in primary and secondary schools after the exclusion of thedata related to 
one rural primary school (previously described). In more concrete terms, although the reduction of student absenteeism was steeper in secondary schools, confirming that the activities within Component 2 (peer support, information on absence, the inclusion of parents, support measures for students, etc.) were effective, an important lesson can be observed from the case of primary schools-in order to track students, schools need to have reliable information on their whereabouts outside school, which implies that parents should regularly report on absence from school, especially in situations where absence is closely connected to the status risk factors (i.e. family migrations related to season work). Nevertheless, the results pointed out that school can influence the deep and systemic dropout risk factors that are often beyond the narrow perception of the school's scope of influence (e.g. poverty) and that it can help the most vulnerable students remain in the education system. Such finding also stresses the necessity to involve parents in a variety of activities that are supportive both to them and to the students at risk. Indirectly, this again implies that only when all components of the DPM are intertwined together, connecting the school and teachers with students and their parents, the DPM reaches its full potential.

\section{Limitation and further research}

The sampling in the present study did not foresee a control group of participating schools. Rather, we opted for biased sampling, meaning the most vulnerable schools were selected to examine the effectiveness of the DPM. At the same time, to address the lack of control group, the data before the intervention had been collected for a longer period of time than it would have been the case in a classical quazi-experimental design. Also, in order to achieve the full implementation of the recommended DPM, schools usually need support outside the education sector (e.g., social welfare and protection, civil and business sector, local self-governments), but not all schools are in the position to obtain such support due to the huge differences in local contexts. Therefore, the DPM should be introduced by the education authorities as mandatory, which will ensure sustainability of the model, as well as participation of the relevant actors at the local level. Therefore, since it is clear that the education system cannot prevent the students' dropout alone and that the part of the dropout risk factors is outside the education sector, further research should be focused on mapping the cooperation patterns and gaps in such cooperation between actors from different relevant sectors at the national level and the level of local self-governments, including identification of the good practice examples. Consequently, such research should be the foundation for the development of the integrative dropout prevention model. 


\section{References}

Balfanz, R., Herzog, L., \& Mac Iver, D. J. (2007). Preventing student disengagement and keeping students on the graduation path in urban middle-grades schools: Early identification and effective interventions. Educational Psychologist, 42, 223-235.

Bowers, A. J., Sprott, R., \& Taff, S. (2013). Do we know who will drop out? A review of the predictors of dropping out of high school: Precision, sensitivity and specificity. High School Journal, 96(2), 77-100.

Castelli, L., Ragazzi, S., \& Crescentini, A. (2012). Equity in Education: A General Overview. Procedia - Social and Behavioral Sciences, 69, 2243-2250.

Duchesne, S. \& Ratelle, C. (2010). Parental Behaviors and Adolescents' Achievement Goals at the Beginning of Middle School: Emotional Problems as Potential Mediators. Journal of Educational Psychology, 102(2), 497-507.

Dustmann, C., \& van Soest, A. (2008). Part-time work, school success and school leaving. Empirical Economics, 32, 277-299.

Dynarski, M., \& Gleason, P. (2002). How can we help? What we have learned from recent federal dropout prevention evaluations. Journal of Education For Students Placed At Risk, 7(1), 43-69.

Engeström, Y. (1987). Learning by expanding learning by expanding. An activity theoretical approach to developmental research. Helsinki: Orienta-Konsultit.

Engeström, Y., (2000). Activity theory as a framework for analysing and redesigning work. Ergonomics, 43(7), 960-974.

Engeström, Y., (2001). Expansive Learning at Work: Toward an activity theoretical reconceptualization, Journal of Education and Work, 14(1), 133-156.

European Commission (2013). Reducing early school leaving: Key messages and policy support. Retrieved from http://ec.europa.eu/education/policy/strategic-framework/doc/esl-group-report_en.pdf.

Felner, R., Seitsinger, A., Brand S., Burns, A., \& Bolton, N. (2007). Creating Small Learning Communities: Lessons From the Project on High-Performing Learning Communities About "What Works" in Creating Productive, Developmentally Enhancing, Learning Contexts. Educational Psychologist, 42(4), 209-221.

Freeman, J., \& Simonsen, B. (2015). Examining the Impact of Policy and Practice Interventions on High School Dropout and School Completion Rates: A Systematic Review of the Literature. Review of Educational Research, 85(2), 205-248.

Goldschmidt, P., \& Wang, J. (1999). When can schools affect dropout behavior? Alongitudinal multilevel analysis. American Educational Research Journal, 36, 715-738.

Government of the Republic of Serbia (2012). Strategy for education development in Serbia 2020. Official Gazette of Republic of Serbia 107/2012.

Heckman, J. (2008). Schools, skills and synapses. Economic Inquiry, 46(3), 289-324.

Jovanović, V., Čekić Marković, J., Jokić, T., \& Ranković, T. (2017). Effectiveness of Individualised Support Measures in Dropout Prevention Model (DPM) in Serbian Schools. Psihološka istraživanja, 20(1), 171-193. 
Kovač Cerović, T., Cenerić, I., \& Jokić, T. (2017). Kako do kvalitetne dopunske nastave - oslonci za unapređenje i primeri dobre prakse. Beograd: Centar za obrazovne politike.

Lansford, J. E., Dodge, K. A., Petit, G.S., \& Bates, J.E., (2016). A Public Health Perspective on School Dropout and Adult Outcomes: A Prospective Study of Risk and Protective Factors From Age 5 to 27 Years. Journal of Adolescent Health, 58, 652-658.

Lee, V. E., \& Burkam, D. T. (2003). Dropping out of high school: The role of school organization and structure. American Educational Research Journal, 40, 353-393.

Lehr, C. A., Hansen, A., Sinclair, M. F., \& Christenson, S. L. (2003). Moving beyond dropout towards school completion: An integrative review of data-based interventions. School Psychology Review, 32, 342-364.

Lopez Bernal, J., Cummins, S. \& Gasparrini, A. (2016). Interrupted time series regression for the evaluation of public health interventions: a tutorial. International Journal of Epidemiology, DOI: 10.1093/ije/dyw098

Mac Iver, M. A. (2011). The challenge of improving urban high school graduationoutcomes: Findings from a randomized study of dropout prevention efforts. Journalof Education For Students Placed At Risk, 16, 167-184.

Multiple Indicator Cluster Survey 2014 (2015). Serbia Multiple Indicator Cluster Survey 2014: Monitoring the situation of children and Women. Beograd: Unicef, Republički zavod za statistiku, Republika Srbija.

Government of the Republic of Serbia (2009). Law on Foundations of the Education System. Official Gazette of Republic of Serbia. No. 72/2009.

Government of the Republic of Serbia (2013). Law on Primary Education. Official Gazette of Republic of Serbia, No. 55/13.

Government of the Republic of Serbia (2013). Law on Secondary Education. Official Gazette of Republic of Serbia, No. 55/13.

Pavlović Babić, D., Krstić, K., Stepanović, I., Videnović, M., Lazarević, L., Simić, N., \& Marković, O. (2013). Analiza faktora koji utiču na osipanje iz osnovnog i srednjeg obrazovanja. Beograd: Institut za psihologiju, Unicef Srbija. Unpublished manuscript.

Prevatt, F., \& Kelly, F. D. (2003). Dropping out of school: A review of intervention programs. Journal of School Psychology, 41, 377-395.

Statistical Office of the Republic of Serbia (2013). Population education attainment, literacy and computer literacy data by municipalities and cities. Belgrade: Statistical Office of the Republic of Serbia.

Statistical Office of the Republic of Serbia (2015). Statistical Yearbook of the Republic of Serbia - Education. Belgrade: Statistical Office of the Republic of Serbia.

Riehl, C. (1999). Labeling and letting go: An organizational analysis of high school students who are discharged as dropouts. Research in Sociology of Education and Socialization, 12, 231-268.

Rumberger, R. W. (1983). Dropping out of high school: The influence of race, sex and family background. American Educational Research Journal, 20, 199-220. 
Rumberger, R. W. (1995). Dropping out of middle school: A multilevel analysis of students and schools. American Educational Research Journal, 32, 583-625.

Rumberger, R. W. (2001). Why students drop out of school and what can be done. Paper prepared for the Conference, Dropouts in America: How Severe is the Problem? What Do We Know about Intervention and Prevention? Harvard University, January 13, 2001.

Rumberger, R. W. \& Lim, S. A. (2008). Why students drop out of school: A review of 25 years of research. California Dropout Research Project Report. Retrieved from http://www.issuelab.org/resources/11658/11658.pdf.

Rumberger, R. W., \& Rotermund, S. (2012). The relationship between engagement andhigh school dropout. In S. L. Christenson, A. L. Reschley, \& C. Wylie (Eds.), Handbook of research on student engagement (pp. 491-513). New York, NY: Springer Science.

UNESCO (2015). Incheon Declaration - Education 2030: Towards inclusive and equitable quality education and lifelong learning for all. World Education Forum. Retrieved from https:/en.unesco.org/world-education-forum-2015/.

Wehlage, G. G., \& Rutter, R. A. (1985). Dropping out: How much do schools contribute to the problem? Teachers College Record, 87, 374-392.

White, S. W., \& Kelly, F. D. (2010). The school counselor's role in school dropout prevention. Journal of Counseling \& Development, 88, 227-235. 


\title{
Razvoj modela za prevenciju i intervenciju u cilju sprečavanja osipanja učenika u osnovnom i srednjem obrazovanju u Srbiji: Procena efikasnosti modela
}

\author{
Jasminka Čekić Marković
}

Centar za obrazovne politike

\section{Jelena Radišić}

Odeljenje za obrazovanje nastavnika i istraživanja u školi,

Fakultet obrazovnih nauka, Univerzitet u Oslu

\section{Vitomir Jovanović}

Centar za obrazovne politike

\section{Tanja Ranković}

UNICEF Srbija

Rad se bavi problemom osipanja učenika iz obrazovnog sistema u Srbiji, ukazujući na potrebu za prevencijom osipanja unutar sistema obrazovanja. Posmatrajući koncept osipanja kao multidimenzionalni fenomen koji zahteva opservaciju i tretman na nivou sistema, razmatramo model usmeren na prevenciju i intervenciju $\mathrm{u}$ vezi sa sprečavanjem osipanja učenika iz sistema pred-univerzitetskog obrazovanja. Model uzima u obzir karakteristike škola u Srbiji i uključuje raznolikost potreba učenika pod rizikom od osipanja iz obrazovanja. Analize su usmerene na četiri indikatora - osipanje, apsentizam, ponavljanje razreda i postignuće učenika, u svetlu podataka prikupljenih u osnovnim i srednjim stručnim školama gde je model pilotiran. Rezultati ukazuju da je model najefikasniji kada je reč o smanjenju osipanja, apsentizma i stope ponavljanja razreda, a da su neophodne dalje analize kada je reč o postignućima učenika. 


\section{Appendix 1. Criteria for the Selection of Municipalities for a Broad Sample of Schools}

Municipalities wereselected according to the formula for calculating the composite score $(\mathrm{Y})$ after the linear compression of variables in which a municipality that has the lowest value on the criterion (variables) gets the value 0 and the one with the maximum value on the criterion gets the value 1. Thus, the transformed criteria get weights according to the formula:

$$
Y=0.3^{\star} a_{1}+0.3^{\star} a_{2}+0.1^{\star} a_{3}+0.1^{\star} a_{4}+0.1^{\star} a_{5}+0.1^{\star} a_{6}
$$

Municipal Development Index $\left(a_{1}\right)$ - this index contains:

1) Material aspect of the index, covering total consumption at the municipal level (household expenses, municipal charges and energy consumption). The material part of the index approximates the risks of ESL because it indicates the general economic situation in the municipality.

2) Social aspect of the development index, which consists of the part related to education and healthcare. It indicates the number of medical staff per 1.000 inhabitants, the rate of infant mortality and the level of education of the population.

Percentage of Roma in the municipality $\left(\mathrm{a}_{2}\right)$ - poverty is one of the main reasons for dropping out, and the Roma population does not complete primary and secondary education to the greatest extent. They live in deepest poverty and dropout for children from Roma families is highly probable (Multiple Indicator Cluster Survey 2014, 2015).

The number of students aged from 0 to 17 in the municipality $\left(a_{3}\right)$ and the number of primary and secondary schools $\left(\mathrm{a}_{6}\right)$ - this variable is taken as a part of the composite index for the selection of municipalities because findings suggest that early childhood development has a very positive influence on later outcomes, whether they are viewed in the context of skills, competencies, income or other positive social outcomes (Heckman, 2008).

Coverage by preschool education of children aged 0 to $6\left(\mathrm{a}_{5}\right)$ - indicates the extent to which parents are informed about the existing education resources for their children; as this measure is obligatory.

Coverage by the preparatory preschool program $\left(a_{4}\right)$ - indicates the extent to which parents are informed about the existing education resources for their children; as this measure is obligatory. 


\section{Appendix 2. Example of the questionnaire sections for primary schools in the baseline assessment}

The questionnaire included the following quantifiable sections:

1) Basic data about the school - total number of teachers, classes, students (by gender, grade, Roma students, students refugees and internally displaced persons, students attending teaching under the IEP 1, IEP 2 and IEP 3, students living in families that are beneficiaries of any kind of assistance from the system of social protection, students living with only one parent, students living without parents or in foster families).

2) Average achievement per grade at the end of the school year for the defined school year

3) Average achievement per grade at the end of thefirst semester for the defined school year

4) Number of students who have interrupted their education per grade and the defined school year

5) The reason for leaving school (the number of students with a short description of the reason)

6) Total number of excused absences per grade for the specified school year

7) Total number of unexcused absences per grade for the specified school year

8) Total number of students who repeated a grade for the specified school year

The questionnaire included the following sections that describe specific school policies:

a) Describe five examples of cooperation, if any, that you had with institutions and community organisations in order to prevent student dropout from school. Choose those cases that best illustrate the quality of cooperation between the school and institutions/organisations.

b) Describe academic procedures that the school applies if a teacher or a professional associate remarked that a student is at risk of school dropout that you intend to continue with even after the completion of the project.

c) Does the school cooperate with the parents of students who are at risk of dropout? If you cooperate, describe how and in what way.

d) Does the school provide free meals to poor students? If provided, how is this being done, and from which funds?

e) How does your school organise remedial classes? Who attends themand for what reasons? What kind of a relationship doremedial class teachers and students have? Do students and teachers treat students attending 
remedial classes as students who are unsuccessful? What are the criteria by which students are included in the remedial classes?

f) Is the practice of peer support present in the school?

g) What are all the extracurricular activities and extra activities in your school? 